\title{
TINDAK PIDANA PENCUCIAN UANG DENGAN KEJAHATAN ASAL TINDAK PIDANA NARKOBA PADA PUTUSAN MAHKAMAH AGUNG RI NO. 1303 K/PID.SUS/2013 JO. PUTUSAN PENGADILAN TINGGI MEDAN NO. 700/PID/2012/PT.MDN JO. PUTUSAN PENGADILAN NEGERI MEDAN NOMOR 1243/PID.B/2012/PN.MDN
}

\author{
Ferdy Saputra \\ Fakultas Hukum Universitas Malikussaleh \\ Jl. Jawa, Kampus Bukit Indah, Kota Lhokseumawe - Banda Aceh \\ Email: ferdysaputraagani@gmail.com
}

\begin{abstract}
Abstrak
Pencucian uang tidak hanya mengancam stabilitas ekonomi dan integritas sistem keuangan, tetapi juga membahayakan sendi kehidupan masyarakat, bangsa, dan negara berdasarkan Pancasila dan Undang-Undang Dasar Negara Republik Indonesia Tahun 1945 Pencucian uang yang dilakukan adalah untuk menyamarkan hasil kejahatan. Dalam hal ini, akan diangkat berdasarkan kejahatan narkotika dan narkoba. Terkait dengan studi kasus berdasarkan Putusan Mahkamah Agung No. 1303 K / Pid.Sus / 2013 tanggal 21 Agustus 2013 Jo. Bidang Pengadilan Tinggi No. 700 / Pid / 2012 / PT.Mdn tanggal 8 Januari 2013 Jo. Putusan Pengadilan Negeri Medan No. 1243 / Pid.B / 2012 / PN.Mdn tanggal 8 Oktober 2012 juga menggunakan modus kejahatan di bidang perbankan. Mode kejahatan di sektor perbankan, dalam hal ini, menggunakan layanan pengiriman uang Money Changer (penukaran uang). Predicate crime (asal kejahatan) itu adalah obat tindak pidana, yaitu metamfetamin. Perdagangan metamfetamin dilakukan antara lintas negara, yaitu antara Malaysia dan Indonesia.
\end{abstract}

\section{Kata Kunci: Pencucian, Uang, Kejahatan, Narkoba, Putusan}

\section{Abstract}

Money laundering is not only threatening the economic stability and integrity of the financial system, but also harm the joints of the life of society, nation, and state based on Pancasila and the Constitution of the Republic of Indonesia Year 1945 Money laundering is done is to disguise the proceeds of crime. In this case, will be appointed on the crime of narcotics and drugs. Related with the case studies in based on the Supreme Court Decision No. 1303 K / Pid.Sus / 2013 dated August 21, 2013 Jo. High Court Field No. 700 / Pid / 2012 / PT.Mdn dated January 8, 2013 Jo. Medan District Court Decision No. 1243 / Pid.B / 2012 / PN.Mdn dated October 8, 2012 also uses the mode of crimes in the banking field. Mode of crime in the banking sector, in this case, use money transfer services Money Changer (money changers). Predicate crime (crimes origin) it is a criminal offense drug, namely methamphetamine. Methamphetamine trade is carried out between cross country, namely between Malaysia and Indonesia.

Keywords: Money Laundering, Money, Crime, Narchotic, Verdict

\section{PENDAHULUAN}

Kejahatan peredaran gelap narkoba sejak lama diyakini memiliki kaitan erat dengan proses pencucian uang. Sejarah perkembangan tipologi pencucian uang menunjukkan bahwa 
DE LEGA LATA

Jurnal Ilmu Hukum

FAKULTAS HUKUM UMSU
Tindak Pindana Pencucian...(Ferdy Saputra)

Volume 3 Nomor 2, Juli-Desember 2018, 244-256 DOI: https://doi.org/10.30596/dll.v3i2.3161

perdagangan obat bius merupakan sumber yang paling dominan dan kejahatan asal (predicate crime) yang utama yang melahirkan kejahatan pencucian uang. Organized crime selalu menggunakan metode pencucian uang ini untuk menyembunyikan, menyamarkan atau mengaburkan hasil bisnis haram itu agar nampak seolah-olah merupakan hasil dari kegiatan yang sah. Selanjutnya, uang hasil jual beli narkoba yang telah dicuci itu digunakan lagi untuk melakukan kejahatan serupa atau mengembangkan kejahatan-kejahatan baru (Yunus Husein, 2004, h. 1).

Pada umumnya tindak pidana pencucian uang dilakukan dalam bidang perbankan. Adapun bentuknya yaitu pelaku tindak pidana berusaha menyembunyikan atau menyamarkan asal usul harta kekayaan yang merupakan hasil dari tindak pidana dengan berbagai cara agar harta kekayaan hasil kejahatannya sulit ditelusuri oleh aparat penegak hukum sehingga dengan leluasa memanfaatkan harta kekayaan tersebut baik untuk kegiatan yang sah maupun tidak sah. Kegiatan pencucian uang hampir selalu melibatkan perbankan karena adanya globalisasi perbankan sehingga melalui sistem pembayaran terutama yang bersifat elektronik (electronic funds transfer), dana hasil kejahatan yang pada umumnya dalam jumlah besar akan mengalir atau bahkan bergerak melampaui batas negara dengan memanfaatkan faktor rahasia bank yang umumnya dijunjung tinggi oleh perbankan (M. Zainul Hafizi, 2011).

Pencucian uang atau dalam Bahasa Inggris disebut Money Laundering tidak hanya mengancam stabilitas perekonomian dan integritas sistem keuangan, tetapi juga membahayakan sendi-sendi kehidupan bermasyarakat, berbangsa, dan bernegara berdasarkan Pancasila dan Undang-Undang Dasar Negara Republik Indonesia Tahun 1945. Pencucian uang dilakukan adalah untuk menyamarkan uang hasil tindak pidana (Peter Reuter dan Edwin M. Truman, 2004, h. 1-8). Dalam hal ini, akan diangkat tentang tindak pidana narkotika dan obat-obat terlarang. Tindak pidana narkoba yang disamarkan adalah uang hasil penjualannya agar dianggap halal dan legal. Narkoba yang diedarkan sudah jelas akan dijual kepada pemakai, setelah dijual barulah uang yang didapat akan dibuat suatu usaha atau apapun bentuknya untuk melegalkan uang tersebut, sehingga tersamarlah uang hasil penjualan narkoba tadi, oleh sebab itulah disebut pencucian uang (Lucky Nurhadiyanto, 2010, h. 161).

Dikaitkan dengan studi kasus pada penelitian ini, yaitu terhadap Putusan Mahkamah Agung RI No. 1303 K/Pid.Sus/2013 tanggal 21 Agustus 2013 Jo. Putusan Pengadilan Tinggi Medan No. 700/Pid/2012/PT.Mdn tanggal 8 Januari 2013 Jo. Putusan Pengadilan Negeri Medan No. 1243/Pid.B/2012/PN.Mdn tanggal 8 Oktober 2012 juga menggunakan modus kejahatan dalam bidang perbankan. Modus kejahatan dalam bidang perbankan, dalam hal ini, menggunakan jasa pengiriman uang di money changer (tempat penukaran uang). Predicate crime (kejahatan asal)-nya adalah tindak pidana narkoba, yaitu shabu-shabu. Perdagangan shabu-shabu ini dilakukan antar lintas negara yaitu antara Malaysia dengan Indonesia.

Pada Putusan Mahkamah Agung RI No. 1303K/Pid.Sus/2013 tanggal 21 Agustus 2013 Jo. Putusan Pengadilan Tinggi Medan No. 700/Pid/2012/PT.Mdn tanggal 8 Januari 2013 Jo. Putusan Pengadilan Negeri Medan No. 1243/Pid.B/2012/PN.Mdn tanggal 8 Oktober 2012 menarik diteliti karena putusan tersebut pada tingkat Pengadilan Negeri di dalam amarnya 
DE LEGA LATA

Jurnal Ilmu Hukum

FAKULTAS HUKUM UMSU
Tindak Pindana Pencucian...(Ferdy Saputra)

Volume 3 Nomor 2, Juli-Desember 2018, 244-256 DOI: https://doi.org/10.30596/dll.v3i2.3161

yang menjatuhkan pidana penjara terhadap Terdakwa Maha Nathy Naidu alias Rendy dengan pidana penjara selama 3 (tiga) tahun dan 6 (enam) bulan dan denda sebesar Rp. 1.000.000.000,- (satu miliar rupiah) subsidair 4 (empat) bulan penjara. Sedangkan, pada putusan tingkat Pengadilan Tinggi, Terdakwa Maha Nathy Naidu tersebut dihukum oleh Majelis Hakim dengan pidana penjara selama 6 (enam) tahun dan denda sebesar Rp. 2.000.000.000,- (dua miliar rupiah) dan apabila denda tersebut tidak dibayar dapat diganti dengan pidana kurungan selama 6 (enam) bulan. Selanjutnya dalam putusan pengadilan pada tingkat Mahkamah Agung telah memutus dengan amarnya menghukum Terdakwa tersebut dengan hukuman penjara selama 6 (enam) bulan dan denda sebesar Rp. 37.000.000.000,- (tiga puluh tujuh miliar rupiah). Perbedaan penghitungan denda inilah yang menarik untuk diteliti, mengenai dari mana asalnya Majelis Hakim Pengadilan Tinggi memutus untuk menaikkan denda dari Rp. 1 miliar ke Rp. 2.000.000.000,- (Dua Miliar Rupiah), sedangkan Majelis Hakim Agung pada Mahkamah Agung menghukum Terdakwa dengan denda sebesar Rp. 37.000.000.000,- (Tiga Puluh Tujuh Miliar). Sementara itu, harta Terdakwa tidak sampai dengan angka yang dikehendaki oleh Majelis Hakim Agung sebesar Rp. 37 37.000.000.000,(Tiga Puluh Tujuh Miliar).

Berdasarkan uraian di atas dapat dilihat bahwa ada hubungan antara pencucian uang dan dunia kejahatan tindak pidana narkoba. Oleh sebab itu, Tindak Pidana Pencucian Uang Dengan Kejahatan Asal Tindak Pidana Narkoba Pada Putusan Mahkamah Agung RI No. 1303 K/PID.SUS/2013 Jo. Putusan Pengadilan Tinggi Medan No. 700/PID/2012/PT.MDN Jo. Putusan Pengadilan Negeri Medan No. 1243/Pid.B/2012/PN.Mdn penting untuk dikaji dan diteliti karena terdapat beberapa persoalan menarik di dalamnya.

\section{METODE PENELITIAN}

Penelitian ini adalah penelitian yuridis normatif bersifat deskriptif analisis. Jenis data yang digunakan adalah data sekunder yang bersumber dari bahan hukum primer, sekunder, dan tertier. Data sekunder dikumpulkan dengan teknik studi kepustakaan. Selanjutnya, datadata tersebut dianalisa dengan menggunakan metode analisa kualitatif. Adapun permasalahan yang dirumuskan dalam penelitian ini adalah analisis yuridis tindak pidana pencucian uang dan kejahatan asal tindak pidana kejahatan Narkoba pada Putusan Pengadilan Negeri Medan No. 1243/Pid.B/2012/PN.Mdn., tanggal 08 Oktober 2012.

\section{PEMBAHASAN}

\section{Hubungan Tindak Pidana Pencucian Uang Dengan Kejahatan Asal Tindak Pidana Narkoba}

Hukum tindak pidana narkotika termasuk dalam kategori yang bermotifkan "economic gain" atau menghasilkan keuntungan ekonomi, terlebih dilakukan oleh korporasi atau organisasi kriminal atau sindikat. Dapat dipastikan akan bersinergi dengan tindak pidana pencucian uang untuk mengaburkan hasil kejahatan tersebut. Diperlukan koordinasi antar lembaga penegakan hukum dalam menangani permufakatan jahat dalam tindak pidana narkoba dengan tindak pidana pencucian uang karena memang hasil tindak pidana narkotika 
DE LEGA LATA

Jurnal Ilmu Hukum

FAKULTAS HUKUM UMSU
Tindak Pindana Pencucian...(Ferdy Saputra)

Volume 3 Nomor 2, Juli-Desember 2018, 244-256 DOI: https://doi.org/10.30596/dll.v3i2.3161

sangat menjanjikan keuntungan yang sangat besar (Djoko Sarwoko, 2013).

Perlunya sinergitas penegak hukum antara penyidik BNN, Polri bekera sama dengan PPATK serta perbankan untuk menelusuri transaksi keuangan yang dilakukan oleh pelaku baik individu maupun korporasi dengan menggunakan pendekatan "follow the money". Dari penelusuran dan hasil analisis dari PPATK, maka akan diketahui aliran dana atau transfer dan siapa pelakunya apakah individu atau korporasi. Jika pelakunya korporasi, maka perlu diteliti lagi siapa yang bertanggung jawab apakah pengurus korporasi, pengendali atau orang yang melaksanakan perintah untuk dan atas nama yang berbasis kepentingan korporasi atau 'corporate liability'.

Penyidikan kekayaan tersebut, perlu dikembangkan jika hasilnya signifikan, harus ditelusuri kemana saja transaksi keuangannya dengan minta laporan hasil harta kekayaan anak beserta istrinya seperti dalam Pasal 97 dan Pasal 98 Undang-Undang Nomor 35 Tahun 2009 tentang Narkotika. Atau adakah kemungkinan bahwa hasil kejahatan narkotika tersebut dipergunakan untuk mendanai kegiatan terorisme. Hal ini perlu dicermati karena kemungkinan bersar hasil kejahatannya dipergunakan untuk membantu kegiatan teror, terutama jika pelaku adalah korporasi, bandar narkotika, sindikat, atau organisasi kriminal.

Di dalam penanganan kejahatan narkoba dan TPPU, proses hukum tersebut terbentur undang-undang yang belum mengatur kasus tersebut secara satu atap, yakni terpisah antara Undang-Undang No. 35 Tahun 2009 No. 1243/Pid.B/2012/PN.Mdn. tertanggal 08 Oktober 2012 tentang Narkotika dan Undang No. 8 Tahun 2010 tentang Pencegahan danPemberantasan Tindak Pencucian Pencucian Uang. Dakwaan tindak pidana pencucian uang (TPPU) dalam kasus narkoba dapat disusun dalam bentuk subsidaritas karena undangundang yang ada masih berbenturan terkait kewenangan penyidik untuk menangani kedua kasus yang berbeda namun berkaitan tersebut

Di dalam Pasal 137 Undang-Undang Nomor 35 Tahun 2009 mengatur tentang minimum khusus, sedangkan Undang-Undang Nomor 8 Tahun 2012 tidak mengatur hal itu. Sebetulnya Pasal 137 Undang-Undang Nomor 35 Tahun 2009 tentang Narkotika secara substansial mengandung unsur-unsur yang serupa dengan unsur-unsur dalam Pasal 3 UndangUndang Nomor 8 Tahun 2010 tentang Pencegahan danPemberantasan Tindak Pencucian Pencucian Uang. Oleh karena itu, dakwaan TPPU dapat disusun dalam bentuk subsidaritas dakwaan pencucian uang dahulu karena BNN memperoleh menyidik TPPU berdasarkan Pasal 74 Undang-Undang Nomor 8 Tahun 2010, kemudian subsidairnya Pasal 137 Undang-Undang Nomor 35 Tahun 2009 tentang Narkotika. Sehingga Penyidik BNN tetap dapat melakukan penyidikan TPPU yang diduga melanggar Pasal 137 huruf a dan b. Undang-Undang Nomor 35 Tahun 2009. Dari aspek sejarah, mengapa pembentuk undang-undang mencantumkan Pasal 137 pada Undang-Undang Nomor 35 Tahun 2009, dikarenakan untuk mengantisipasi seandainya Pasal 74 Undang-Undang Nomor 8 Tahun 2010 tidak mengatur kewenangan penyidik tindak pidana asal (BNN) melakukan penyidikan TPPU ((Djoko Sarwoko, 2013)).

Meskipun termasuk dalam TPPU, hasil kejahatan narkotika yang dikaburkan melalu pencucian uang, sasaran subjeknya tidak seluas yang diatur dalam Pasal 3 Undang-Undang 
Tindak Pindana Pencucian...(Ferdy Saputra) DOI: https://doi.org/10.30596/dll.v3i2.3161

No. 8 Tahun 2010. Rumusan delik Pasal 3 Undang-Undang No. 8 Tahun 2010 dikatakan lebih luas sasaran subjeknya karena mengandung frasa 'yang diketahui atau patut diduganya merupakan hasil tindak pidana sebagaimana dimaksud dalam Pasal 2 ayat (1), terdapat 26 jenis tindak pidana termasuk narkotika.

Pasal 137 huruf b Undang-Undang No. 35 Tahun 2009 yang telah diadopsi dalam Pasal 4 Undang-Undang No. 8 Tahun 2010 berisi ancaman pidana yang lebih berat, yakni penjara paling lama 20 tahun dengan denda paling banyak Rp. 5 miliar dan jika denda tidak dibayar, maka diganti dengan kurungan selama satu tahun empat bulan. Lebih berat jika dibandingkan Undang-Undang No. 35 Tahun 2009 yang tunduk pada Pasal 30 ayat (6) KUHP yang mengatur pidana kurungan pengganti tidak boleh dari delapan bulan.

Apabila dikaitkan dengan Putusan Pengadilan Negeri Medan No. 1243/Pid.B/2012/PN.Mdn., tanggal 08 Oktober 2012 dalam penelitian ini, Terdakwa Maha Nathy Naidu alias Rendy dihukum berdasarkan Pasal 137 huruf b. Undang-Undang No. 35 Tahun 2009 tentang Narkotika. Terdakwa Maha Nathy Naidu alias Rendy telah terbukti secara sah dan meyakinkan sebagai orang yang menerima penempatan, pembayaran atau pembelanjaan, penitipan, penukaran, penyembunyian atau penyamaran investasi, simpanan atau transfer, hibah, waris, harta atau uang, benda atau aset baik dalam bentuk benda bergerak atau tidak bergera, berwujud atau tidak berwujud yang diketahuinya berasal dari tindak pidana narkotika dan/atau tindak pidana prekursor narkotika. Adapun yang menjadi unsur yang utama dalam ketentuan Pasal 137 huruf b. tersebut adalah Terdakwa harus mengetahui bahwa uang yang diterimanya adalah berasal dari tindak pidana narkotika.

Mengenai pembuktian unsur "Yang Diketahuinya Berasal Dari Tindak Pidana Narkotika" sangat sulit dibuktikan karena Terdakwa Maha Nathy Naidu alias Rendy tidak tahu sama sekali uang tersebut dari mana masuknya. Terdakwa Maha Nathy Naidu hanya mengetahui bahwa uang yang diterimanya itu adalah berasal dari transfer Bapak Kamal sebagai teman ayahnya Maha Nathy Naidu yaitu Bayu yang bergerak dalam bidang usaha money changer. Usaha Bapak Kamal tersebut juga menerima uang dari Tenaga Kerja Indonesia (TKI) yang berada di Malaysia untuk selanjutnya ditransfer kepada keluarga TKI yang ada di Indonesia. Hal inilah yang disusupi oleh mafia narkoba dengan membuat kerjasama dengan Bapak Kamal sehingga akhirnya shabu-shabu dari Malaysia masuk ke Indonesia melalui Tanjung Balai.

Di dalam penyidikan tindak pidana pencucian uang menurut Undang-Undang No. 8 Tahun 2010 tentang Pencegahan dan Pemberantasan Tindak Pidana Pencucian Uang, pihak yang berwenang melakukan penyidikan atas pencucian uang adalah PPATK. Lalu, dalam hal ini, PPATK telah memberikan hasil laporannya kepada Badan Narkotika Nasional (BNN) Provinsi Sumatera Utara, sehingga akhirnya BNN melimpahkan perkara tersebut ke Kejaksaan Tinggi Sumatera Utara untuk disidangkan.

\section{Analisa Yuridis Tindak Pidana Pencucian Uang dan Kejahatan Asal Tindak Pidana Kejahatan Narkoba pada Putusan Pengadilan Negeri Medan No. 1243/Pid.B/2012/PN.Mdn., tanggal 08 Oktober 2012}


DE LEGA LATA

Jurnal Ilmu Hukum

FAKULTAS HUKUM UMSU
Tindak Pindana Pencucian...(Ferdy Saputra)

Volume 3 Nomor 2, Juli-Desember 2018, 244-256 DOI: https://doi.org/10.30596/dll.v3i2.3161

Batasan pertimbangan hukum dalam hukum pidana formil diartikan suatu tahapan dimana majelis hakim mempertimbangkan fakta-fakta yang terungkap selama persidangan berlangsung, mulai dari dakwaan, eksepsi, pemeriksaan bukti-bukti dan saksi-saksi, tuntutan, pledoi, replik, duplik, putusan. Dalam pertimbangan hukum dicantumkan pula pasal-pasal dari peraturan hukum yang dijadikan dasar dalam putusan tersebut. Dalam praktek, landasan yang dijadikan hakim dalam sebuah putusan disistematisasikan dalam bagian mengingat. Pertimbangan hukum dimulai dengan kata "menimbang ...dan seterusnya".

\section{Pertimbangan Hukum Majelis Hakim pada Pengadilan Negeri Medan}

Pada Putusan Pengadilan Negeri No. 1243/Pid.B/2012/PN.Mdn., tertanggal 08 atas nama Terdakwa Maha Nathy Naidu alias Rendy telah diputus berdasarkan Pasal 137 huruf $b$. Undang-Undang No. 35 Tahun 2009 tentang Narkotika. Pada pertimbangan hukumnya Terdakwa Maha Nathy Naidu alias Rendy adalah orang yang menerima penempatan berupa transfer uang yang diketahuinya berasal dari tindak pidana narkotika.

Unsur "Menerima Penempatan Berupa Transfer Uang" pada Putusan Pengadilan Negeri tersebut telah dipenuhi dengan pertimbangan bahwa: Terdakwa Maha Nathy Naidu alias Rendy telah membuka rekening atas nama dirinya, Namdewa, dan W. Wijen Khrisna dan menggunakan rekening-rekening tersebut untuk menampung pembayaran/transfer uang yang menurut Terdakwa Maha Nathy Naidu adalah berasal dari transfer uang Kamal dari Malaysia yang berasal dari transfer uang Tenaga Kerja Indonesia (TKI), akan tetapi, ternyata telah terbukti secara sah dan meyakinkan Suryono alias Aweng yang memiliki barang berupa shabu kepunyaan Anly Yusuf alias Mami yang berasal dari Ramli Petrus alias Abeng, Anly Yusuf alias Mami membayarkan pembayaran shabu tersebut kepada Ramli Petrus alias Abeng kepada rekening Terdakwa Maha Nathy Naidu, Namdewa, dan W. Wijen Khrisna. Oleh karena itu, unsur “Menerima Penempatan Berupa Transfer Uang” telah terpenuhi.

Pada pertimbangan majelis hakim Pengadilan Negeri tersebut telah melakukan pemeriksaan terhadap berkas-berkas terpisah, atas nama Suryono alias Aweng sebagai pengedar shabu, Anly Yusuf alias Mami sebagai pemilik shabu yang diedarkan Suryono alias Aweng, dan Ramli Petrus alias Abeng sebagai gembong shabu yang menyuruh Anly Yusuf alias Mami untuk membayar shabu tersebut kepada Terdakwa Maha Nathy Naidu alias Rendy, Namdewa, dan W. Wijen Khrisna.

Berdasarkan Putusan Pengadilan Negeri Medan No. 470/Pid.B/2012/PN-Mdn., tertanggal 12 Juli 2012 Jo. Putusan Pengadilan Tinggi Medan No. 450/Pid/2012/PT-Mdn., tertanggal 31 Agustus 2012, Ramli Petrus alias Abeng Ramli Petrus alias Abeng telah terbukti secara sah dan meyakinkan bersalah melakukan tindak pidana :

1) Tanpa hak dan melawan hukum melakukan permufakatan jahat menjual dan membeli atau menyerahkan Narkotika Golongan I dalam bentuk bukan tanaman beratnya lebih 5 Gram;

2) Membayarkan atau membelanjakan uang harta dalam bentuk benda bergerak yang berasal dari tindak pidana narkotika; Menjatuhkan pidana terhadap Terdakwa tersebut dengan pidana penjara selama 8 (delapan) tahun dan pidana denda sebesar Rp. 1.500.000.000,- 
DE LEGA LATA

Jurnal Ilmu Hukum

FAKULTAS HUKUM UMSU
Tindak Pindana Pencucian...(Ferdy Saputra) Volume 3 Nomor 2, Juli-Desember 2018, 244-256 DOI: https://doi.org/10.30596/dll.v3i2.3161

(satu miliar lima ratus juta rupiah) dengan ketentuan jika denda tidak dibayar diganti dengan pidana penjara selama 6 (enam) bulan;

Menetapkan masa penahanan yang telah dijalani Terdakwa dikurangkan seluruhnya dari pidana yang dijatuhkan. Menetapkan Terdakwa tetap dalam tahanan. Menetapkan supaya barang bukti berupa:

1) Narkotika Golongan I jenis bukan tanaman seberat 12,7 Gram sisa dari 1.197 Gram yang telah dimusnahkan sesuai dengan Berita Acara Pemusnahan Barang Bukti, tanggal 04 Januari 2012 sebanyak 1.184,3 Gram dan 1 (satu) buah HP merek Nokia warna hitam serta 1 (satu) buah alat hisap (bong) dirampas untuk dimusnahkan;

2) Uang sebesar Rp. 6.100.000,- (enam juta seratus ribu rupiah) dan Rp. 45.000.000,- (empat puluh lima juta rupiah) dirampas untuk Negara; c. 1 (satu) buah KTP atas nama Ramli Petrus, 1 (satu) buah SIM A atas nama Ramli Petrus dan 1 (satu) unit kendaraan Toyota Avanza Nopol : BL-1448-KW berikut kunci, STNK, dan BPKB dikembalikan kepada Terdakwa.

Majelis Hakim yang memutus perkara Anly Yusuf alias Mami telah menjatuhkan hukuman penjara selama 10 tahun. Putusan tersebut menyatakan Terdakwa Anly Yusuf alias Mami telah terbukti secara sah dan meyakinkan, melakukan tindak pidana tanpa hak dan melawan hukum, melakukan permufakatan jahat memperjualbelikan narkotika Golongan I, bukan tanaman yang beratnya lebih dari 5 gram. Selain dinyatakan melanggar Pasal 114 ayat (2) Undang-Undang No. 35 Tahun 2009 tentang Narkotika Jo. Pasal 551 ayat (1) ke-1 KUHP, Mami juga dinyatakan terbukti melanggar Pasal 132 huruf $b$. Undang-Undang No. 35 Tahun 2009, karena menyimpan harta hasil transaksi yang diperoleh dari tindak pidana narkotika. Anly Yusuf alias Mami juga dijatuhi sanksi denda sebesar Rp. 1.000.000.000,- (satu miliar rupiah) yang mana apabila tidak dibayarkan maka akan diganti dengan hukuman penjara selama 6 (enam) bulan. Barang bukti yang disita berupa HP Nokia C5, uang Rp. 19.000.000,(sembilan belas juta), serta giwang 3,9 gram dan mengembalikan SIM dan KTP milik Terdakwa, hal yang meringankan Terdakwa bahwa Terdakwa bersikap sopan dalam persidangan, dan yang memberatkan terdakwa masih di hukum, lagi menjalakan hukuman dalam kasus yang sama (Mami BD Shabu, 2012).

Akibat dari perbuatan Anly Yusuf alias Mami tersebut Majelis Hakim menjatuhkan vonis, menambah hukuman yang harus dijalani Anly di penjara. Sebelumnya, perempuan ini juga sudah divonis 10 tahun penjara, karena mengedarkan narkoba jenis sabu-sabu. Belum lama menjalani hukuman di Lapas Wanita Tanjung Gusta, Anly kembali ditangkap tangan oleh Petugas BNN, bersama Wakil Menteri Hukum dan HAM, Denny Indrayana yang menangkapnya di penjara pada 20 Desember 2011, sekitar pukul 03.30 WIB. Menyusul penangkapan sejumlah rekannya Ramli Petrus, dan Suriono alias Aweng yang merupakan kurir atau anggota jaringannya (Mami BD Shabu Divonis 10 Tahun Penjara, 2012).

Fakta dalam persidangan, Anly Yusuf mengaku memerintahkan kurirnya Suriono untuk mengambil sabu-sabu dari rekannya Ramli Petrus, dalam berkas yang terpisah, dan 
DE LEGA LATA

Jurnal Ilmu Hukum

FAKULTAS HUKUM UMSU
Tindak Pindana Pencucian...(Ferdy Saputra)

Volume 3 Nomor 2, Juli-Desember 2018, 244-256 DOI: https://doi.org/10.30596/dll.v3i2.3161

mengantarkan barang ilegal itu kepada langganannya di Medan. Perintah disampaikan melalui telepon selular. Transaksi terjadi berulang-ulang dengan berat sabu-sabu berkilo-kilogram. Sementara itu, pembayaran dilakukan melalui transfer mobile bangking rekening atas nama anak Anly.

Perkara ini menjadi perhatian publik, karena dalam tuntutannya Jaksa hanya menyatakan Anly melanggar Pasal 137 huruf B UU 35 2009, karena menyimpan harta benda hasil tindak pidana narkotika, seperti dakwaan ke-2 primer. Padahal dalam dakwaan ke-1 primer, Jaksa juga menjerat Anly dengan pasal 114 ayat (2) karena mengedarkan narkotika. Dakwaan ini pun sesuai dengan fakta di persidangan. Sidang pembacaan tuntutan juga mengundang kecurigan. Sebab saat itu JPU dalam persidangan hanya berlangsung beberapa menit dan dalam membacakan tuntutanya dibacakan dengan suara sangat pelan. Akhirnya Majelis Hakim telah menjatuhkan putusannya kepada dakwaan Jaksa dan mengukum Anly. Kedua dakwaan primer terbukti dan Anly ahirnya divonis 10 tahun penjara, sama seperti hukuman yang sedang dijalaninya akibat kasus serupa. Anly terbukti mengulangi perbuatannya mengedarkan narkotika (Mami BD Shabu Divonis 10 Tahun Penjara, 2012).

Kasus tersebut terbongkar pada tanggal 21 Desember 2011, ketika Wakil Menteri Hukum dan HAM, Denny Indrayana bersama Badan Narkotika Nasional (BNN), berhasil menangkap Suryono alias Aweng, dengan brang bukti berupa sabu seberat 206,4 gram. Di kediaman Aweng di Jalan Sengon Sekip, Medan, petugas juga berhasil menyita 0,5 gram sabu-sabu. Dari penyidikan, diketahui barang haram itu milik Anly Yusuf alias Mami, yang dengan bebas mengendalikan peredaran narkoba di dalam penjara. Setelah memiliki bukti cukup kuat atas keterlibatan Anly Yusuf alias Mami, BNN akhirnya melakukan penangkapan dan berhasil menyita uang senilai Rp. 9 juta, dan telepon genggam yang ternyata digunakan untuk mengatur transaksi narkoba di wilayah Sumatera (Moko Dihukum 8 Tahun, 2013).

Jaringan Mami di luar penjara bukan hanya Aweng. Ada beberapa nama lain yang juga turut ditangkap, yaitu Ramli Petrus alias Abeng, yang ditangkap pada bulan Agustus 2011 dengan barang bukti sabu seberat $1 \mathrm{~kg}$. Dari penyidikan, Mami ternyata mengontrol penjualan narkoba itu dari dalam penjara, dengan rincian pada bulan Oktober 2011 transaksi sabu seberat $1 \mathrm{~kg}$, tanggal 17 Desember 2011 juga terjadi transaksi pembelian sabu seberat $1 \mathrm{~kg}$. Kemudian pada tanggal 20 Desember 2011, Mami menghubungi Aweng, memerintahkan mengambil sabu-sabu seberat 200 gram dari tersangka Abeng dan Alwi (sudah divonis) (Moko Dihukum 8 Tahun, 2013).

Dari sana Mami kembali mengontrol peredaran sabu-sabu seberar 206,4 gram dari para kurir. Mami memerintahkan dua orang kurirnya membagi sabu kepada Asiong seberat 50 gram, Keling 50 gram, Said 100 gram. Tetapi saat dilakukan penangkapan, tiga kaki tangan Mami, berhasil kabur, dan hanya Aweng yang berhasil ditangkap. Pada berkas dakwaan JPU, ternyata sabu itu diperoleh Mami dari Abeng, dan Tri Sudiatmoko alias Moko Narapidana LP Dewasa Tanjung Gusta Medan pada bulan November 2011 seberat 2 ons dengan harga Rp 65 juta per ons (Moko Dihukum 8 Tahun, 2013).

Unsur "Yang Diketahuinya Dari Tindak Pidana Narkotika" pada Putusan Pengadilan 
DE LEGA LATA

Jurnal Ilmu Hukum

FAKULTAS HUKUM UMSU
Tindak Pindana Pencucian...(Ferdy Saputra) Volume 3 Nomor 2, Juli-Desember 2018, 244-256 DOI: https://doi.org/10.30596/dll.v3i2.3161

Negeri Medan tersebut telah terbukti secara sah dan meyakinkan Terdakwa Maha Nathy Naidu dengan sengaja membuka rekening-rekening bank atas nama saudara-saudaranya yaitu Namdewa dan W. Wijen Khrisna sehingga dapat menerima uang transfer dari pengakuan Anly Yusuf alias Mami yang membayarkan shabu tersebut kepada rekening-rekening yang dibuka oleh Terdakwa Maha Nathy Naidu alias Rendy. Oleh karena itu, unsur "Yang Diketahuinya Dari Tindak Pidana Narkotika" telah terbukti secara sah dan meyakinkan.

Pertimbangan majelis hakim pengadilan negeri tersebut berasal dari pemeriksaan berkas-berkas perkara atas nama Suryono alias Aweng, Anly Yusuf alias Mami, dan Ramli Petrus alias Abeng. Berasal dari putusan tersebutlah Terdakwa Maha Nathy Naidu alias Rendy sebagai pengembangan Penyidik BNN yang akhirnya disidangkan di Pengadilan Negeri Medan, dan majelis hakim dapat memberikan pertimbangan berupa asumsi bahwa Terdakwa Maha Nathy Naidu alias Rendy telah mengetahui bahwa uang yang diterimanya adalah berasal dari hasil tindak pidana narkotika berupa shabu-shabu.

Terdakwa Maha Nathy Naidu alias Rendy dihukum berdasarkan Pasal 137 huruf b. Undang-Undang No. 35 Tahun 2009 tentang Narkotika dengan hukuman penjara selama 3 (tiga) tahun. Sehingga Terdakwa Maha Nathy Naidu alias Rendy megajukan banding ke Pengadilan Tinggi Medan melalui Akta Permintaan Banding No. 213 dan 214/Akta.Pid/2012/PN.Mdn., tanggal 17 Oktober 2012.

\section{Pertimbangan Hukum Majelis Hakim Tinggi Pada Pengadilan Tinggi Sumatera Utara}

Setelah menyatakan banding terhadap Putusan Pengadilan Negeri Medan No. 1243/Pid.B/2012/PN.Mdn., tertanggal 08 Oktober 2012, Terdakwa Maha Nathy Naidu membuat memori banding dengan kesimpulan sebagai berikut:

1) "Pembacaan putusan bersifat tidak sempurna";

2) Putusan Majelis Hakim tanggal 10 Oktober 2012 No. 1243/Pid.B/2012/PN.Mdn bertentangan dengan Pasal 200 KUHAP;

3) Putusan Majelis Hakim dalam perkara pidana atas nama Maha Nathy Naidu alias Rendy tidak memberikan pertimbangan hukum yang cukup;

4) Putusan Majelis Hakim tanggal 10 Oktober 2012 No. 1243/Pid.B/2012/PN.Mdn tidak memenuhi persyaratan undang-undang;

5) Majelis Hakim Pengadilan Negeri telah melanggar ketentuan Pasal 185 ayat (1) KUHAP;

6) Putusan Majelis Hakim tanggal 10 Oktober 2012 Nomor 1243/Pid.B/2012/PN.Mdn salah menerapkan hukum". (Putusan Pengadilan Tinggi Medan No. 700/Pid/2012/PT-Mdn., tertanggal 08 Januari 2013, h. 64).

Adapun pertimbangan Majelis Hakim Tinggi pada perkara tersebut pada pokoknya tetap menjatuhkan sanksi pidana dengan menggunakan Pasal 137 huruf b. Undang-Undang No. 35 Tahun 2009 tentang Narkotika. Akan tetapi, berbeda pendapat terhadap pidana yang dijatuhkan kepada Terdakwa Maha Nathy Naidu alias Rendy, sebagai berikut (Putusan Pengadilan Tinggi Medan No. 700/Pid/2012/PT-Mdn., tertanggal 08 Januari 2013: 68-69):

Menimbang, bahwa namun demikian Majelis Hakim Tinggi tidak sependapat dengan 
DE LEGA LATA

Jurnal Ilmu Hukum

FAKULTAS HUKUM UMSU
Tindak Pindana Pencucian...(Ferdy Saputra)

Volume 3 Nomor 2, Juli-Desember 2018, 244-256 DOI: https://doi.org/10.30596/dll.v3i2.3161

Majelis Hakim Tingkat Pertama perihal lamanya pidana yang dijatuhkan terhadap Terdakwa, mengingat perbuatan Terdakwa telah mendukung maraknya peredaran narkotika di Indonesia, yang menurut Majelis Hakim Tinggi sudah mewabah dalam masyarakat Indonesia, dan telah melibatkan serta menghantui semua etnis, semua agama, bahwa sudah dijadikan sasaran empuk bagi pengedar narkotika internasional, sehingga pemberantasan peredaran narkotika perlu dilakukan secara lebih serius, sehingga pidana yang dijatuhkan Majelis Hakim Tingkat Pertama dipandang terlalu ringan dan tidak sesuai dengan keadilan masyarakat.

Menimbang, bahwa selain hal-hal yang memberatkan sebagaimana telah dipertimbangkan oleh Majelis Hakim Tingkat Pertama dalam putusannya itu, pertimbangan yang memberatkan sebagaimana diuraikan diatas dapat dijadikan dasar untuk menambah lamanya pidana yang harus dijatuhkan terhadap Terdakwa, dan Majelis Hakim Tinggi berpendapat pidana sebagaimana disebutkan dalam amar putusan ini adalah tepat dan adil bagi Terdakwa dan juga bagi masyarakat Indonesia;

Menimbang, bahwa dengan demikian alasan Penasehat Hukum Terdakwa dalam kesimpulan memori bandingnya pada point 3, 4 dan 6 tidak berlasan karenanya akan dikesampingkan sedang kesimpulan memori bandingnya pada point 1,2 dan 5 tidak termasuk dalam lingkup pemeriksaan dalam tingkat banding ini oleh karenanya juga harus dikesampingkan.

Majelis Hakim Tinggi pada Pengadilan Tinggi Sumatera Utara di Medan berdasarkan uraian-uraian di atas telah memutus memperbaiki sekedar mengenai pidana yang dijatuhkan kepada Terdakwa sedangkan putusan selebihnya dapat dikuatkan. Sehingga pidana yang dijatuhkan kepada Terdakwa Maha Nathy Naidu menjadi 6 (enam) tahun penjara.

Pada Putusan Pengadilan Negeri Medan No. 1243/Pid.B/2012/PN.Mdn., tertanggal 08 Oktober 2012 Jo. Putusan Pengadilan Tinggi Medan No. 700/Pid//2012/PT-Mdn., tertanggal 08 Januari 2013 telah diputus Terdakwa Maha Nathy Naidu alias Rendy telah terbukti secara sah dan meyakinkan bersalah melakukan tindak pidana "Menerima Penempatan Berupa Transfer Uang Yang Diketahuinya Berasal Dari Tindak Pidana Narkotika" sebagaimana dimaksud Pasal 137 huruf b. Undang-Undang No. 35 Tahun 2009 tentang Narkotika.

Ketentuan yang diterapkan dalam perkara tersebut adalah ketentuan yang berasal dari ketentuan narkotika, yang mana apabila dilihat lebih lanjut sangat tipis perbedaan dengan ketentuan pencucian uang. Perbedaan ketentuan tersebut terletak dari tindak pidananya, apabila Undang-Undang Narkotika menkhususkan kepada tindak pidana narkotika, sedangkan pada Undang-Undang TPPU hanya terdapat frase "tindak pidana" yang artinya dapat dilihat pada Pasal 2 UU TPPU.

Terhadap ketentuan pidana yang diterapkan (apakah menggunakan UU Narkotika atau UU TPPU) adalah kewenangan penyidik dalam hal ini Badan Narkotika Nasional (BNN) yang melakukan pengembangan terhadap kasus narkotika. BNN mencari aliran dana dengan mengikuti aliran uang pembayaran dari pengedar narkoba yang didapati hilirnya pada rekening-rekening yang dibuka oleh Terdakwa Maha Nathy Naidu alias Rendy.

Dakwaan Tindak Pidana Pencucian Uang (TPPU) dalam kasus narkoba dapat disusun dalam bentuk subsidaritas karena undang-undang yang ada masih berbenturan terkait dengan 
DE LEGA LATA

Jurnal Ilmu Hukum

FAKULTAS HUKUM UMSU
Tindak Pindana Pencucian...(Ferdy Saputra) Volume 3 Nomor 2, Juli-Desember 2018, 244-256 DOI: https://doi.org/10.30596/dll.v3i2.3161

kewenangan penyidik untuk menangani kedua kasus yang berbeda namun berkaitan tersebut.

\section{Perbedaan Putusan Pengadilan Negeri Medan No. 1243/Pid.B/2012/PN.Mdn., tertanggal 08 Oktober 2012 dengan Putusan Pengadilan Tinggi Medan No. 700/Pid/2012/PT.Mdn., tertanggal 08 Januari 2013}

Perbedaan Putusan Pengadilan Negeri Medan No. 1243/Pid.B/2012/PN.Mdn., tertanggal 08 Oktober 2012 dengan Putusan Pengadilan Tinggi Medan No. 700/Pid/2012/PT.Mdn., tertanggal 08 Januari 2013 terletak pada pidana penjara yang dijatuhkan. Pada Putusan Pengadilan Negeri Medan, Terdakwa Maha Nathy Naidu telah dijatuhkan pidana penjara selama 3 (tiga) tahun dan 6 (enam) bulan lamanya sedangkan Putusan Pengadilan Tinggi Medan menjatuhkan pidana penjara selama 6 (enam) tahun. Kedua putusan tersebut telah tepat dan benar menurut hukum dalam menentukan lamanya pidana penjara yang dijatuhkan.

Perbedaan putusan dalam hal pidana penjara tersebut dikarenakan, pertimbangan Majelis Hakim Tinggi pada Pengadilan Tinggi Medan lebih luas cakupannya dari pada Majelis Hakim Tingkat Pertama pada Pengadilan Negeri Medan yang tidak ada sama sekali pertimbangan hukumnya. Akan tetapi, pertimbangan hukum Majelis Hakim Tinggi tersebut sudah keluar dari konteks perkara yang diperiksa karena berangkat dari perbuatan Terdakwa yang mendukung maraknya peredaran narkotika di Indonesia. Majelis Hakim Tinggi tidak dapat membuktikan apakah perbuatan Terdakwa Maha Nathy Naidu alias Rendy - lah yang memarakkan peredaran gelap narkotika di Indonesia.

\section{KESIMPULAN DAN SARAN \\ Kesimpulan}

Pertimbangan Majelis Hakim pada tingkat pertama dan banding terhadap tindak pidana pencucian uang dan tindak pidana kejahatan asal tindak pidana kejahatan narkoba terkait dengan Putusan Pengadilan Negeri Medan No. 1243/Pid.B/2012/PN.Mdn., tanggal 08 Oktober 2012 adalah bahwa pertimbangan majelis hakim pengadilan negeri tersebut berasal dari pemeriksaan berkas-berkas perkara atas nama Suryono alias Aweng, Anly Yusuf alias Mami, dan Ramli Petrus alias Abeng. Berasal dari putusan tersebutlah Terdakwa Maha Nathy Naidu alias Rendy sebagai pengembangan Penyidik BNN yang akhirnya disidangkan di Pengadilan Negeri Medan, dan majelis hakim dapat memberikan pertimbangan berupa asumsi bahwa Terdakwa Maha Nathy Naidu alias Rendy telah mengetahui bahwa uang yang diterimanya adalah berasal dari hasil tindak pidana narkotika berupa shabu-shabu. Sehingga, Terdakwa Maha Nathy Naidu alias Rendy dihukum berdasarkan Pasal 137 huruf b. UndangUndang Nomor 35 Tahun 2009 tentang Narkotika dengan hukuman penjara selama 3 (tiga) tahun.

Pada Putusan Pengadilan Negeri Medan No. 1243/Pid.B/2012/PN.Mdn., tertanggal 08 Oktober 2012 Jo. Putusan Pengadilan Tinggi Medan No. 700/Pid//2012/PT-Mdn., tertanggal 
08 Januari 2013 telah diputus Terdakwa Maha Nathy Naidu alias Rendy telah terbukti secara sah dan meyakinkan bersalah melakukan tindak pidana "Menerima Penempatan Berupa Transfer Uang Yang Diketahuinya Berasal Dari Tindak Pidana Narkotika" sebagaimana dimaksud Pasal 137 huruf b. Undang-Undang No. 35 Tahun 2009 tentang Narkotika. Berdasarkan azas hukum Lex Specialis Derrogat Lex Generalis, Majelis Hakim yang memutus perkara tersebut harus menerapkan pidana yang berasal dari ketentuan hukum yang lebih khusus.

\section{Saran}

Bahwa memberikan kesadaran bagi setiap subjek hukum khususnya bagi manusia adalah tidak mudah karena harus dilalui dengan proses yang lama dan panjang, apalagi terkait dengan kesadaran hukum bahwa menerima uang berasal dari yang tidak halal sangat susah untuk dilakukan dan banyaknya tindakan pencucian uang yang dilakukan oleh gembong narkoba. Penerima uang dari hasil kejahatan tersebut pada dasarnya haruslah sadar dengan menerima hasil kejahatan tersebut sama saja dengan bekerja sama dengan cara berupaya menyamarkan hasil kejahatan yang dilakukan oleh gembong narkoba tersebut. Oleh karena itu peningkatan kesadaran bagi setiap orang terkait dengan dilarangnya untuk menerima uang hasil kejahatan atau bahkan setidak-tidaknya menerima uang dari hasil yang tidak diketahui asalnya haruslah patut dicurigai. Bahkan tindakan melaporkan kepada pihak bank atas uang yang telah diterimanya dari asal yang tidak jelas. 
Jurnal Ilmu Hukum

FAKULTAS HUKUM UMSU
Tindak Pindana Pencucian...(Ferdy Saputra) Volume 3 Nomor 2, Juli-Desember 2018, 244-256 DOI: https://doi.org/10.30596/dll.v3i2.3161

\section{DAFTAR PUSTAKA}

Hafizi. M. Zainul. (2011) Makalah Etika Bisnis Penegakan Hukum Terhadap Pencucian Uang di Indonesi. Jakarta: Universitas Indraprasta PGRI

Husein, Yunus. (2004). Hubungan Antara Kejahatan Peredaran Gelap Narkoba dan Tindak Pidana Pencucian Uang. Paper pendukung Delegasi RI pada Forthy-Seventh Session of The Comission on Narcotics Drugs yang diselenggarakan di Wina 15-22 Maret 2004,

Mami BD Shabu Divonis 10 Tahun Penjara. (12 JUli 2012). Harian Medan Bisnis.

Moko Dihukum 8 Tahun (4 November 2013). Harian Medan Bisnis.

Nurhadiyanto, Lucky. (2010). Pola Pencucian Uang Hasil Perdagangan Narkoba dan Pembalakan Liar. Jurnal Kriminologi Indonesia, Vol. 6. No. II. Agustus 2010,

PPATK E-Learning. tanpa tahun. "Modul E-Learning 1 : Pengenalan Anti Pencucian Uang dan Pendanaan Terorisme". Jakarta : PPATK.

Putusan Mahkamah Agung RI No. 1303 K/Pid.Sus/2013 tanggal 21 Agustus 2013.

Putusan Pengadilan Negeri Medan No. 1243/Pid.B/2012/PN.Mdn tanggal 8 Oktober 2012.

Putusan Pengadilan Tinggi Medan No. 700/Pid/2012/PT.Mdn tanggal 8 Januari 2013.

Reuter. Peter., \& Truman, Edwin M. (2004). Chasing Dirty Money: The Fight Against Money Laundering. US: Automated Graphic Systems. Inc.

Sarwoko, Djoko. (23 November 2013). Antara Narkotika dan Pencucian Uang. Harian Republika

Soesilo. R.. 1985. Kitab Undang-Undang Hukum Pidana Serta Komentar-Komentar Lengkap Pasal Demi Pasal. Bogor: Politeia.

Sudjono Iswahyudi : Politik Hukum Pemberantasan Korupsi :Lex Specialis Systematic Versus Lex Specialis Derogat Lege Generali (15 Oktober 2007). Harian Media Indonesia.

Undang-Undang Nomor 10 Tahun 1998 tentang Perbankan.

Undang-Undang Nomor 35 Tahun 2009 tentang Narkotika.

Undang-Undang Nomor 8 Tahun 1981 tentang Kitab Undang-Undang Hukum Acara Pidana.

Undang-Undang Nomor 8 Tahun 2010 tentang Pencegahan dan Pemberantasan Tindak Pidana Pencucian Uang. 